\title{
Tinospora mahajanii (Menispermaceae), a new species from Khandwa district, Madhya Pradesh, India
}

\author{
Mishra S. ${ }^{1 *}$, Khristi S.M. ${ }^{2}$ \& C.M. Solanki ${ }^{3}$ \\ ${ }^{1}$ Department of Botany, S.N. Govt. P.G. College, Khandwa, Madhya Pradesh - 450 001, India. \\ ${ }^{2}$ Department of Genetics, Ashok \& Rita Patel Institute of Integrated Study \& Research in Biotechnology and Allied Sciences, \\ New V.V. Nagar, Anand, Gujarat - 388 121, India. \\ ${ }^{3}$ Ex-Principal, Department of Botany, P.M.B. Gujarati Science College, Indore, Madhya Pradesh - 452 007, India. \\ *E-mail: dr.shakunmishra2012@gmail.com
}

\begin{abstract}
Tinospora mahajanii (Menispermaceae), a new species from the Awalya forest range of Khandwa district, Madhya Pradesh, India, is described here along with colour photographs, micrographs of endocarp and comparison with its allied species $T$. neocaledonica Forman and T. sinensis (Lour.) Merr. The species is unique in having inflorescences with lateral branches, stems with a yellowish watery sap and sub-elliptic drupes. Comparison with its allied species, habitat and distribution are provided to aid identification.
\end{abstract}

Keywords: Awalya forest, India, Menispermaceae, New species, Tinospora.

\section{Introduction}

The genus Tinospora Miers comprises about 32 species and is distributed throughout tropical Africa, Madagascar, Asia to Australia and the Pacific Islands (Forman, 1981; Kessler, 1993; Pramanik \& Gangopadhyay, 1993; Mabberley, 2008; Udayan \& Pradeep, 2009; Mujaffar et al., 2014; Rajendran et al., 2016). The genus Tinospora is represented by nine species in India viz., $T$. sinensis (Lour.) Merr. (synonym T. cordifolia (Willd.) Hook.f. \& Thomson), T. crispa (L.) Hook.f. \& Thomson, T. glabra (Burm.f.) Merr., T. formanii Udayan \& Pradeep, T. maqsoodiana Mujaffar, Moinudd. \& Mustakim and T. smilacina Benth. from the southern Western Ghats (Rajendran et al., 2016); T. subcordata Diels, T.

Received: 25.01.2020; Revised \& Accepted: 06.10.2020

Published Online: 31.12 .2020 neocaledonica Forman and T. baenzigeri Forman (Mishra, 2020; Mishra \& Mishra, 2020; Mishra et al., 2020) from Madhya Pradesh.

During recent field explorations in various parts of the forests of Central India, the authors collected a species of Tinospora from the Awalya forest range of Khandwa district in Madhya Pradesh. Further studies showed that the specimens represented a new species which is described here. A comparison of morphological characters of closely similar species of Tinospora is provided in Table 1 to facilitate precise identification.

\section{Materials and Methods}

Fresh specimens of T. mahajanii were collected from the Awalya forest range, Khandwa district, Madhya Pradesh during the month of December 2016. Detailed examination of all the materials available were done under a stereo zoom microscope. Morphology of the specimens was compared with allied species. Herbarium specimens were prepared as per Bridson and Forman (1991). The novelty of the taxon was confirmed by a critical morphological analysis of the specimens, comparison with the relevant literature and on discussion with experts.

\section{Taxonomic treatment}

Tinospora mahajanii Mishra, Khristi \& Solanki, sp. nov.

Figs. $1 \& 2$

Tinospora mahajanii is morphologically allied to $T$. neocaledonica and $T$. sinensis but differs by having stems 

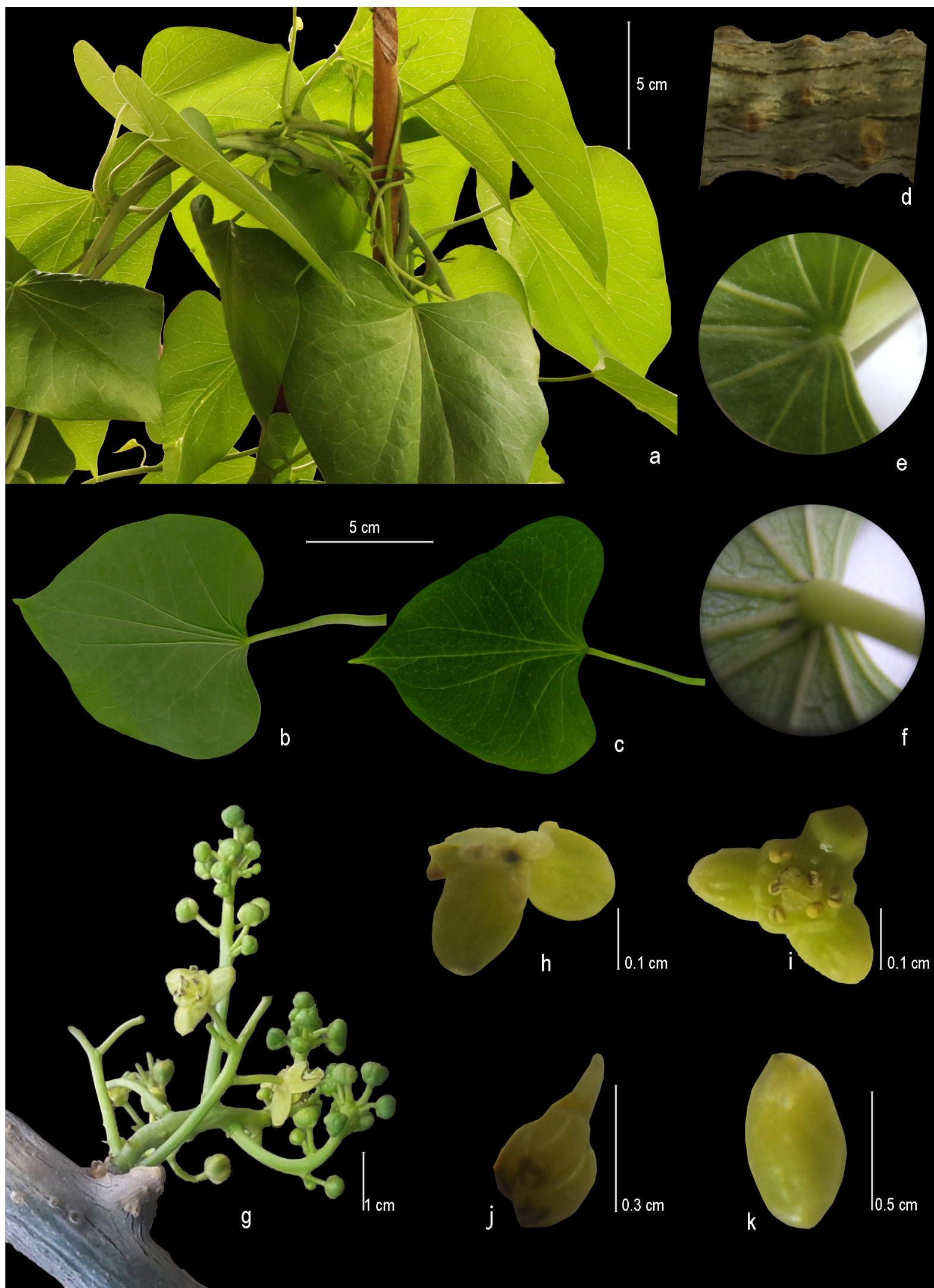

Fig. 1. Tinospora mahajanii Mishra, Khristi \& Solanki: a. Branch; b. Leaf-dorsal view; c. Leaf-ventral view; d. Segment of stem; e. Ventral leaf base showing glandular-papillose patches; f. Dorsal leaf base showing nine veins; g. Female inflorescence; h. Female flower-back view; i. Female flower-front view; j. Carpophore; k. Sepal (a-k from Mishra 201262; photos by D. Mishra). 


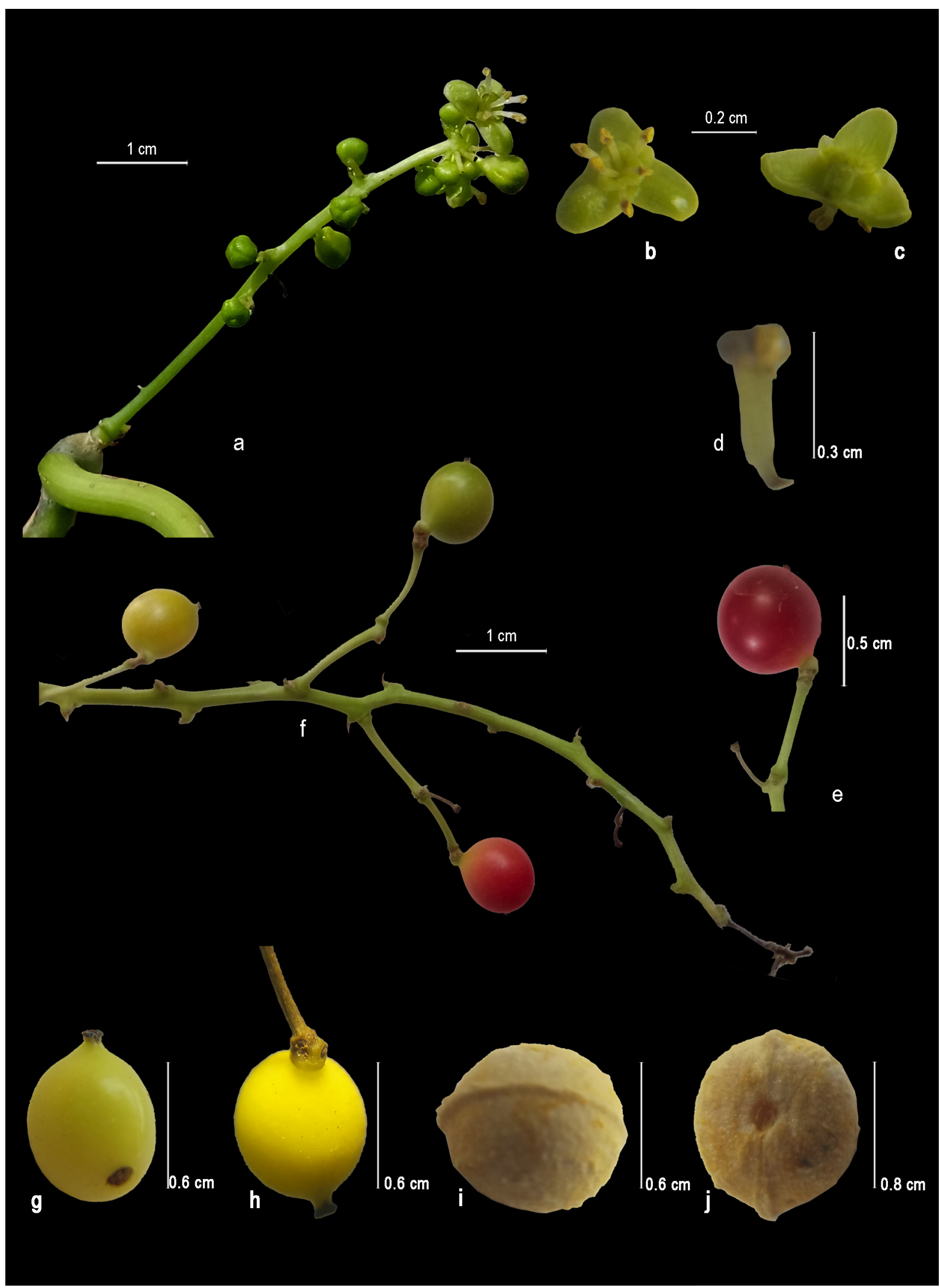

Fig. 2. Tinospora mahajanii Mishra, Khristi \& Solanki: a. Male inflorescence; b. Male flower - front view; c. Back view; d. Stamen; e. Drupe; f. Infructescences; g. \& h. Drupes; i. Endocarp-dorsal view j. Endocarp-ventral view (a-j from Mishra 201262; photos by D. Mishra). 
verruculose; scattered lenticels with a yellow sap; petioles slightly swollen and geniculate at base; male inflorescence coetaneous with the leaves and axillary to branch-scars; female inflorescence a cluster of elongated panicles on branch scars; petals unguiculate and drupes sub-elliptic, become orange-red when ripe.

Type: INDIA, Madhya Pradesh, Khandwa district, Awalya forest range, N $21^{\circ} 48^{\prime} 53.0$ ', E 76 21'34.4", 318 m, 20.12.2016, Mishra 201262 (holo CAL!; iso BSI!).

Perennial, woody, dioecious climbers, with yellowish watery sap when cut; the bark rough and exfoliates in papery flakes and entirely glabrous often with short filiform aerial roots. Stems $0.2-4 \mathrm{~cm}$ in diam., slightly fleshy, green when young, later becoming prominently verruculose and bearing scattered, lenticels first lens-shaped, 2-dehiscent, then rounded, 4-dehiscent, branch scars prominent. Leaves simple, alternate; petioles $2-5(-10) \mathrm{cm}$ long, $0.1-0.3 \mathrm{~mm}$ diam., slightly swollen and geniculate at base; lamina broadly ovate, $6-14 \times 5-13 \mathrm{~cm}$, base broadly cordate to sub-truncate, apex acuminate, palmately 7-9-nerved at the base, three running up to apex, distinctly looping along margins; reticulation raised on both surfaces, finely glandular-papillose patches present in axils of mature leaves in the adaxial part. Male inflorescences elongated panicles, coetaneous with the leaves, axillary on old branch scars; peduncles slender, (5-)9-14 cm long, with hook-like appendages on surface; bract solitary, subulate, 0.8$1.0 \mathrm{~cm}$ long. Male flowers greenish-yellow; pedicels $0.1-0.3 \mathrm{~cm}$ long; sepals 6 in 2 whorls, free, imbricate, pale green, outer 3 ovate, c. $0.1-0.15 \mathrm{~cm}$ long, inner 3 ovate-elliptic to broadly elliptic, c. $0.3-0.5 \mathrm{~cm}$ long; petals 6 , unguiculate with \pm oblate limb, 0.18-0.2 cm long. Stamens 6, yellow; filaments free, clavate, latrorse, c. $0.3 \mathrm{~cm}$ long. Female inflorescences panicles with lateral branches, on branch-scars, not coetaneous with the leaves; peduncles 5.8-11 cm long, flowers clustered. Female flowers greenish yellow, sepals and petals as in male; staminodes 6 , subulate, c. $0.3 \mathrm{~cm}$ long; carpels 3, curved ellipsoidal, c. $0.3 \mathrm{~cm}$ long, style terminal, stout, stigma sessile, flat, 3-cleft; gynophore c. 0.06-0.1 cm long. Infructescences up to $14 \mathrm{~cm}$ long, lateral branches c. $3 \mathrm{~cm}$ long; drupes 1-2, sub-elliptic, borne on carpophore 1.5$2.0 \mathrm{~cm}$ long, dark yellow when young, orangered when ripe, pericarp mucilaginous, pulpy; endocarp thinly bony, navicular, c. $0.8 \times 0.6 \mathrm{~cm}$, pointed at base, keeled at apex, dorsally convex with a prominent median ridge at both ends, irregularly tuberculate, $0.15-0.2 \mathrm{~cm}$ long from aperture to condyle, endosperm adaxially ruminate.

Vernacular names: Gulvel/Gudvel (Korku); Karial/ Usnaide Veli/Giloya de Veli (Gond); Gahutakli (Nihal).

Flowering \& fruiting: Flowering from October to January and fruiting from January to May.

Habitat: This species grows in loamy soil along with hedges of a cultivated field at an altitude of $318 \mathrm{~m}$. It is rare and sparely distributed in the Awalya forest range along with $T$. sinensis. The associated species in the locality are Calotropis gigantea L. (Asclepiadaceae), Acacia eburnea (L.f.)Willd. (Fabaceae) and Azadirachta indica Juss. (Meliaceae).

Etymology: The specific epithet 'mahajanii' is in honour of Dr. Shrikrishna Mahajan, retired Professor of Botany, Government College, Rajpur, Madhya Pradesh for his valuable contribution in the field of plant taxonomy.

Distribution: Known only from the type locality.

Notes: Tinospora mahajanii is distinct by its broadly ovate, 7-9-nerved lamina; slightly swollen, basally geniculate petioles; male inflorescence coetaneous with the leaves; female inflorescence a panicle with lateral branches, on branch-scars showing presence of unguiculate petals; latrorse stamens and 3, curved, ellipsoidal carpels, terminal style; sub-elliptic and sub-navicular drupes and mucilaginous pericarp. The important distinguished characters with its morphologically allied species, viz., T. neocaledonica and T. sinensis are provided in Table 1. 
Table 1. Comparison of diagnostic characters of T. mahajanii with its two allied species, T. neocaledonica and T. sinensis.

\begin{tabular}{|c|c|c|c|}
\hline Characters & $\begin{array}{l}\text { T. mahajanii Mishra, Khristi \& } \\
\text { Solanki }\end{array}$ & T. neocaledonica Forman & T. sinensis (Lour.)Merr. \\
\hline Stems & Verruculose, scattered lenticels & Scattered lenticels & Scattered lenticels \\
\hline Petioles & $\begin{array}{l}\text { Slightly swollen and } \\
\text { geniculate at base }\end{array}$ & Not swollen at base & Twisted and puberulous \\
\hline Lamina & Broadly ovate, 7-9-nerved & Broadly ovate, 5-7-nerved & Ovate, 5-7-nerved \\
\hline $\begin{array}{l}\text { Male } \\
\text { inflorescence }\end{array}$ & $\begin{array}{l}\text { Coetaneous with the leaves, } \\
\text { axillary to branch-scars }\end{array}$ & $\begin{array}{l}\text { Coetaneous with the leaves, } \\
\text { axillary to leaf-scars }\end{array}$ & $\begin{array}{l}\text { Without leaves, } \\
\text { axil of protruding leaf-scars }\end{array}$ \\
\hline $\begin{array}{l}\text { Female } \\
\text { inflorescence }\end{array}$ & $\begin{array}{l}\text { On branch-scars, cluster } \\
\text { of elongated paniculate }\end{array}$ & Not seen & Arising singly along the axis \\
\hline Petals & Unguiculate & Rhomboid-obovate & Rhomboidal-ovate \\
\hline Stamens & Latrorse & Latrorse & Sub-extrorse \\
\hline Drupes & $\begin{array}{l}\text { Orange-red when ripe; } \\
\text { pericarp mucilaginous, pulpy; } \\
\text { endocarp thinly bony, keeled } \\
\text { at apex, dorsally sub-convex } \\
\text { with a median ridge } \\
\text { prominent at both ends, } \\
\text { surface irregularly tuberculate }\end{array}$ & $\begin{array}{l}\text { Red when ripe; pericarp thin; } \\
\text { endocarp bony pointed at both } \\
\text { ends, acutely at base, dorsal } \\
\text { median ridge prominent } \\
\text { at ends, surface irregularly } \\
\text { tuberculate }\end{array}$ & $\begin{array}{l}\text { Bright orange or scarlet red } \\
\text { when ripe; pericarp thin; } \\
\text { endocarp bony, broadly elliptic } \\
\text { to subrotund in outline, } \\
\text { obtusely pointed at base, } \\
\text { broadly keeled at apex, weak } \\
\text { dorsal ridge, surface slightly } \\
\text { papillose }\end{array}$ \\
\hline
\end{tabular}

\section{Key to the species of Tinospora in India}

1. Climbers producing very long filiform aerial roots

1. Climbers without aerial roots or thin small aerial roots

2. Leaves broadly sinuate T. sinensis

2. Leaves triangular ... 3

3. Stems strongly tuberculate; petals usually $3 \ldots$ T. crispa

3. Stems not tuberculate; petals usually 6 .........

4. Leaves with a pair of hollow domatia in abaxial axils of basal veins. T. baenzigeri

4. Leaves with pappilose-glandular patches in abaxial axils of basal veins ...... T. maqsoodiana

5. Inflorescences with lateral branches, at least towards base T. mahajanii

5. Inflorescences unbranched 6

6. Outer and inner sepals equal T. formanii
6. Outer sepals much smaller than inner sepals.....

7. Leaves with domatia present on abaxial in axils of basal nerve T. glabra

7. Leaves with glandular patches present on abaxial in basal nerve axils .. 8

8. Leaves \pm ovate with sides convexly curved ... T. neocaledonica

8. Leaves \pm triangular to broadly triangular with sides straight or sometimes concave 9

9. Drupes borne on columnar carpophore, 4-5 mm long T. subcordata

9. Drupes borne on sub-globose carpophore, 1.5$2 \mathrm{~mm}$ long T. smilacina

\section{Acknowledgements}

Authors are thankful to Dr. Mukesh Jain, Principal, S.N. Govt. P.G. College, Khandwa and Dr. Arjun Tiwari, Scientist-C, Ministry of Environment, 
Forest and climate change, Government of India for providing necessary facilities; University Grants Commission; C.V.M. University, Vallabh Vidyanagar, Anand; Central Regional Office, Bhopal (M.P.) for funding and Dr. Sudip Ray for encouragements.

\section{Literature Cited}

BRIDSON D. \& L. FORMAN 1991. The herbarium handbook. Royal Botanic Gardens, Kew.

FORMAN L.L. 1981. A revision of Tinospora (Menispermaceae) in Asia to Australia and the Pacific. Kew Bulletin 36(2): 375-421.

KESSLER P.J.A. 1993. Menispermaceae. In: KUBITZKI K., ROHWER J.G \& V. BITTRICH (eds.), Flowering Plants. Dicotyledons. The families and genera of vascular plants. Volume 2. Springer, Berlin. pp. 402-418.

MABBERLEY D.J. 2008. Mabberley's Plants-Book: A portable dictionary of plants, their classification and uses. Third edition, Cambridge University Press, Cambridge.

MISHRA S. 2020. Occurrence of a "New Caledonian" species Tinospora neocaledonica Forman (Menispermaceae) In India. Bioscience Discovery 11(2): 95-99.
MISHRA S. \& D. MISHRA 2020. Occurrence of Tinospora subcordata (Menispermaceae): A new record to flora of India, from Khandwa district, Madhya Pradesh, India. Bioscience Discovery 11(2): 85-89.

MISHRA S., ROY S. \& D. MISHRA 2020. Tinospora baenzigeri (Menispermaceae): A new distribution record for the flora of India, from Burhanpur district, Madhya Pradesh, India. Bioscience Discovery 11(3): 137-141.

MUJAFFAR S., MOINUDDIN S. \& S. MUSTKIM 2014. Tinospora maqsoodiana (Menispermaceae), a new species from Madhya Pradesh, India. Indian Forester 140(5): $528-530$.

PRAMANIK A. \& M. GANGOPADHYAY 1993. Menispermaceae. In: SHARMA B.D., BALAKRISHNAN N.P., RAO R.R. \& P.K. HAJRA (eds), Flora of India. Volume 1. Botanical Survey of India, Kolkata.

RAJENDRAN A., PARTHIPAN M. \& A. SARVALINGAM 2016. Occurrence of an Australian species Tinospora smilacina Benth. (Menispermaceae) in India. Research \& Reviews: Journal of Botany 5(1): 16-18. https://doi.org/ 10.37591/rrjob.v5i1.941.

UDAYAN P.S. \& A.K. PRADEEP 2009. A new species of Tinospora (Menispermaceae) from South India. Edinburgh Journal of Botany 66(1): 77-80. 